Revista de Psicología Vol. 30 (1), 2012 (ISSN 0254-9247)

\title{
Técnicas de intervención dinámica y arte en pacientes con psicopatología severa
}

\author{
Emilia Pérez La Rotta ${ }^{1}$ \\ Pontificia Universidad Javeriana, Colombia
}

Esta investigación es un aporte a la comprensión de los beneficios de la terapia dinámica que involucra el arte con pacientes aquejados de psicopatologías severas. Se trabajó con pacientes diagnosticados con esquizofrenia paranoide y fármacodependencia de una clínica psiquiátrica de Bogotá, Colombia. Se muestran las técnicas y los beneficios del arte en el proceso psicoterapéutico con psicopatologías severas.

Palabras clave: esquizofrenia, farmaco dependencia, psicología dinámica, arte.

\section{Dynamic interventions and art for patients with severe psychopathology}

This study points to the benefits of dynamic psychotherapy with art on patients with severe psychopathology. Participants were patients diagnosed with paranoid schizophrenia and drug abuse, from a psychiatric clinic in Bogotá. Colombia. The paper shows the techniques and the results of art in the psychotherapeutic process.

Key words: Schizophrenia, drug abuse, dynamic psychology, art therapy.

1 Psicóloga de la Universidad Santo Tomás, Bogotá, y Doctora de la Universidad de Lovaina, Bélgica. Miembro de Mentalizarte, empresa dedicada al trabajo, la divulgación y la intervención psicoterapéutica de la psicología y el arte. Directora de EPC Consultores Humanos, empresa de capacitación y desarrollo del talento humano a nivel social y empresarial. Psicoterapeuta, conferencista y docente. Contacto: Universidad Javeriana, Facultad de Psicología, Carrera 7 No 40 - 62, Bogotá, Colombia; epcconsultores@hotmail.com info@epcconsultores.org 

Esta investigación presenta la mirada psicoanalítica respecto a la psicoterapia que utiliza el arte como facilitador del proceso psicoterapéutico. Este tipo de intervención psicológica ha sido beneficiosa y curativa en el tratamiento de diferentes psicopatologías, pues permite la recuperación de diferentes funciones neuropsicológicas que están disminuidas y bloqueadas. De la misma forma facilita y enriquece el proceso psicoterapéutico.

El trabajo de Freud ha inspirado a muchos psicólogos y psicoanalistas a utilizar el arte en el proceso psicoterapéutico. Los descubrimientos de Freud acerca del arte y los artistas son publicados con un intervalo de diez años. En 1913, en Curso Abreviado de Psicoanálisis, dice:

Sobre los problemas que conciernen al propósito del arte y los artistas, verlos psicoanalíticamente permite aclaraciones satisfactorias; otros aspectos se escapan completamente, pero si permite encontrar las impresiones de la infancia y del destino de los artistas de un lado, y de otro, sus obras como reacciones a sus estimulaciones, y el objeto más atrayente, el examen analítico (Freud, 1913, p. 1864-1865).

En 1923 Freud aclara que: "El psicoanálisis en un principio no fue sino un método terapéutico", y agrega:

Yo no quisiera que el interés se fije exclusivamente sobre esta utilización, sino también sobre las verdades que encierra nuestra ciencia, sobre las conclusiones a las que ella nos permite llegar, acerca de lo que toca al hombre más de cerca, su propio ser. En fin sobre las relaciones que esta ciencia descubre, las más variadas formas de la actividad humana. Las investigaciones del psicoanálisis dan luz reveladora en los dominios de la mitología, la ciencia, la literatura y la psicología de los artistas. Los mitos y los cuentos de hadas pueden ser interpretados como los sueńos. Caminos contundentes llevan al impulso y al deseo inconsciente en la realización de una obra de arte. La ciencia provee el desencadenamiento del mundo (Freud, como se cita en Kofman, 1970, p. 9). 


\section{El arte como proceso de transformación}

El arte posee el privilegio singular de poner al desnudo la parte activa y la eficacia, de lo que pasa en los seres humanos, tiende al placer, al deseo, y al goce, y es al goce no necesariamente del placer sino también al goce del dolor, de la identificación con el autor, sea en el teatro, la literatura, la pintura, la danza o la música. Este hecho es simplemente porque el arte es sensación y sentimiento, identificación y catarsis, simbolismo y expresión, y posee muchos aspectos más que trataremos en este escrito. Arte para proyectar, evacuar, cristalizar, para estar mejor, para re-encontrarse y por qué no para curarse.

En la práctica de psicoterapia grupal con arte, las identificaciones de los participantes dan la sensación de diferencias, pero también de identificaciones y asociaciones similares en el sentido profundo de la psiquis colectiva que lleva a ver y pensar, en el planteamiento de Freud, acerca del inconsciente colectivo, cuando dice: "la vida consciente del espíritu se nos muestra muy limitada al lado de la inconsciente. El analítico más sutil, o el más penetrante observador no llega nunca a descubrir sino una mínima parte de los móviles que lo guían" (Freud, 1981, pp. 2063-2064). Es así como la expresión pictórica en una sesión de psicoterapia de grupo desencadena asociaciones e insights que permiten ser poderosamente significativos para el grupo por la identificación inconsciente y pre-consciente de procesos similares y marcados por las etapas del desarrollo picosexual, comunes a los seres humanos, y que afloran en esa colectividad psíquica. La prueba innegable de la pintura, sea del artista o del paciente, es que ambas obras llevan en sus rasgos de color, forma y contenido un mensaje, para sí mismo y para el espectador.

El arte en general tiene implicaciones terapéuticas para todas las expresiones artísticas. Jean Florance, psicoanalista que trabaja el teatro terapéutico en Lovaina, dice:

Yo pongo pues al teatro en una posición de enseñanza. ¿Qué tiene que enseñarnos? ¿Qué, en la realidad de nuestra propia práctica? ¿Qué materia manejamos cuando somos analistas o cuando somos 
psicoterapeutas e invitamos a las personas a utilizar la mediación de la expresión escénica y de la interpretación dramática del arte en general para ayudarles a estar mejor, a re-encontrarse, por qué no a curarse? (Florance, 1992, p. 10).

Parecería que su pensamiento hace unísono con el planteamiento de los postulados de Freud respecto al arte, como depositario de los procesos inconscientes. Esta investigación se propone mostrar a diferentes disciplinas de la salud mental los beneficios de la psicoterapia dinámica que involucra arte.

\section{La expresión artística del enfermo mental}

Durante mucho tiempo el interés y la curiosidad de los psiquiatras se inclinó sobre las obras espontáneas de los enfermos crónicos en hospitales para enfermos mentales. Más tarde se tomaron en consideración las obras de artistas que presentaron durante su vida una enfermedad mental. Se debatieron los problemas del poder creador de la locura, su repercusión sobre las posibilidades artísticas y la desaparición de su obra o su transformación bajo la influencia del estado psicopatológico. Se publicaron múltiples patografías sobre grandes artistas y también otros que no lo eran tanto. En los últimos años, gracias a la creación de la psicoterapia de arte y de talleres de arte en los hospitales psiquiátricos, se recoge sistemáticamente un gran número de documentos que permiten identificar distintas expresiones de la locura que se pueden relacionar e interpretar por medio del psicoanálisis.

El discurso psiquiátrico, el discurso dinámico y el discurso artístico se interesan y trabajan en diferentes ámbitos. Sin embargo, nos llevan a pensar en la unidad de razón y emoción que trabajan estas disciplinas. El artista parte de lo imaginario, de lo simbólico, de lo inconsciente; este imaginario en muchas ocasiones es doloroso, pasa de lo sensorial a lo racional, este quehacer dentro de la civilización se transforma de acuerdo a los períodos en los cuales se ha realizado. 
El gesto es el vehículo de lo inconsciente del ser humano, movido por un deseo inmediato y por una sensibilidad indeterminada. El gesto es una tendencia, es la manifestación de un estado primitivo del ser, estado de manifestación y desorden que no tiene en cuenta el mundo exterior. En el inicio de un trazo hay un gesto, es la forma simbólica de una experiencia imaginaria que no tiene sujeto ni objeto (Joulia, 1993, p. 611).

Ese es el beneficio de una expresión propia, única, estructurada, en los niveles del inconsciente y expresada de forma espontánea; así el arte terapéutico se manifiesta de similar forma.

En la terapia de arte con pintura se hace progresivamente un descubrimiento de la persona. El artista o el paciente no está al acecho de un síntoma, no está para ensanchar un dolor, una herida. Ellos, con su arte, proyectan diferentes aspectos de su ser; esto no quiere decir que no expresen un dolor, una herida o un gozo. En el arte terapéutico, como en el arte, paciente y artista expresan diferentes sentimientos de deseo, tristeza o gozo. El terapeuta busca encontrar aspectos que el paciente pueda ver para descifrar y elaborar.

En las primeras sesiones del proceso psicoterapéutico, los trazos, las formas simbólicas, la experiencia imaginaria, en ocasiones no tienen sujeto ni objeto definido. A lo largo del proceso las pinturas ocupan los espacios antes vacíos, formas que dan lugar a elaboraciones figurativas, abstractas, sensibles; aparecen los síntomas que se mezclan con la forma, con la creatividad y con esa parte única del sujeto que se puede llamar el don o habilidad artística. "La atención, la delicadeza de acompañar al enfermo en un viaje pictórico, permite no cortar lo vivo del sufrimiento pero sí de llevarlo a desanudar a través de repeticiones acabadas, establecidas, que van preparando un derrumbamiento de defensas" (Joulia, 1993, p. 612).

Una paciente diagnosticada psiquiátricamente con esquizofrenia simple inicia psicoterapia de arte y en su proceso dibuja inmuebles figuras simples, geométricas. Durante el tratamiento terapéutico ella evoluciona en su proceso y después de un período de doce meses de sesiones de psicoterapia de arte ella se dibuja vomitando, parecería que 
quiere expulsar su dolor como quien saca de su interior una enfermedad virulenta (ver Figura 1).

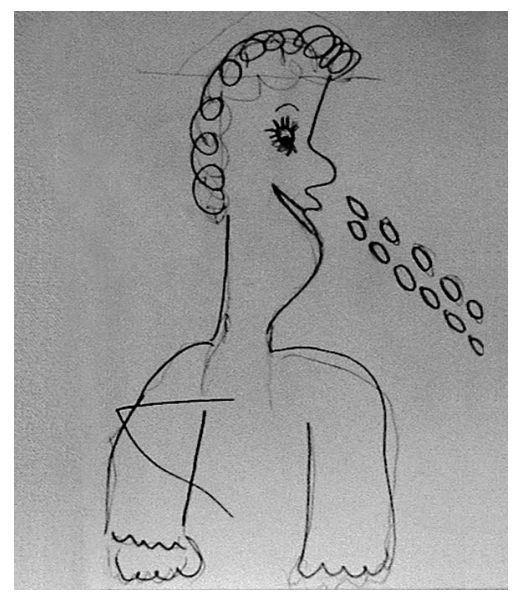

Figura 1. Título Miedo y Ansiedad.

La paciente escribe: tengo mucho miedo y ansiedad y ganas de vomitar, $y$ de no hacer las cosas que me dicen que debo hacer. Me siento con un gran vacio en mi alma y en mi corazón de parte de toda mi familia, de abandono, en especial de mi mamá a la que quiero mucho pero ella impide que yo me acerque, quiero vomitar. Parecería que empieza a poder evacuar su dolor para poder empezar el proceso de elaboración.

La terapia es un proceso de transformación de la persona, el arte es un factor que facilita esta transformación. La terapia y el arte tienden a una unidad, al hecho frecuente de la creación de los artistas, que encierran aspectos inéditos, escandalosos, que no se inscriben en las reglas ni en lo contrario a ellas. "Las formas que los artistas crean son irreductibles, así como las producciones realizadas en terapia. La obra de arte como pluralidad de significados que coexisten en un solo significante de un mensaje fundamentalmente ambiguo, desafía las tentativas de racionalización” (Klein, 1993, p. 613). El sujeto llena de significados un trabajo de arte terapéutico, de la misma forma el artista no puede 
dejar de proyectar aspectos de su inconsciente y de realizar excelentes obras cuando al realizar la obra hay en él un conflicto crítico. De la misma forma que el sujeto impregna su trabajo de arte terapéutico, el artista no puede ignorar una situación similar.

La terapia es transformación de la economía mental, ella es subvertida de normas insatisfechas que triunfan sobre la psicopatología para un propósito, experimentadas en el laboratorio de la transferencia antes de encarnar la vida del sujeto. La expresión no es más que una de las primeras etapas de creación (Klein, 1993, p. 613).

El artista experimenta y vibra a través de su trabajo. Expresa, crea y puede en un momento psicotizarse en función del sentimiento, del dolor o del fracaso; esto lo vemos con frecuencia. La terapia es una expresión catártica que alivia, toma también los elementos psicopatológicos con el vigor de un obrero que trabaja incansablemente. "El artista para ser artista debe ser sujeto de búsqueda personal y profesional para que su interlocutor se ponga en movimiento" (Klein, 1993, p. 613).

\section{Psicoterapia dinámica y arte}

La terapia de arte es una disciplina basada en los campos de la psicología y el arte, manifestando las características de cada una de estas disciplinas como conocimientos del ser humano. Naturalmente que la psicología y el arte son tan antiguas como el ser humano. El desarrollo de la profesión de psicología y el arte puede ser considerada como una aplicación formal a una tradición humana. "La historia de las ciencias y las artes son como un tapiz que se va tejiendo, coloreando, contribuye no solo a una imagen sino también a la fortaleza y estructura de la tela misma” (Vick, 2003, p. 6).

El fundamento para aplicar la psicología al arte fue trabajado por Freud cuando realizó sus investigaciones sobre el arte y los artistas relacionándolos con la psicología, resultado de su quehacer en lo que atañe al ser humano como inherente a él. En este trabajo de investigación 
se pudo observar cómo el arte es un potencializador y facilitador del proceso psicoterapéutico. En la psicoterapia dinámica que utiliza el arte como facilitador y potencializador del proceso se mantienen las técnicas del trabajo dinámico, es decir, es una psicoterapia no directiva que trabaja con la asociación libre para estimular la proyección y el insight, y en la que paciente y terapeuta interpretan los contenidos expresados en el arte.

\section{Técnicas usadas en la investigación}

\section{Modificaciones en el encuadre terapéutico}

Considerando la postura de Frida Fromm Reichmann respecto al encuadre psicoterapéutico, se trabajó teniendo un ambiente cálido y de soporte con los pacientes, pero considerando siempre la neutralidad y la terapia no directiva en el proceso.

La eficacia de la terapia con psicóticos esta en el establecimiento de una transferencia positiva en la que el paciente se sienta comprendido por el terapeuta, el paciente entonces le atribuye todo el poder de una madre ideal, es así como el terapeuta llega a cumplir la función de una objeto reparador y protector. El paciente es tranquilizado y afirmado por las palabras que llevan a calmar sus angustias infantiles y tiene además la función de que el terapeuta pueda penetrar en el universo cerrado del psicótico (Fromm Reichmann, 1978, p. 8).

La postura de Fromm Reichmann, de que la terapia no debe ser distante ni fria porque el paciente llega en busca de lo que no ha tenido, no implica que se pierda la neutralidad. "Sabemos poca cosa acerca del lenguaje del inconsciente del esquizofrénico, así que no debemos sorprendernos de que se produzcan errores y malentendidos cuando trata de comunicarnos" (Fromm Reichmann, 1978, p. 9). Este aspecto lo despeja en parte el trabajo de arte, debido a que la expresión pictórica del paciente en el dibujo aclara diferentes aspectos para él mismo y para 
el terapeuta; el paciente expresa, proyecta y construye en el trabajo que ha realizado y lo complementa con un escrito. El terapeuta afirma, pregunta, complementa e interpreta con el paciente el contenido del trabajo (lo expresado en el dibujo).

Heinz Kohut fue un analista instructor en el Instituto de Psicoanálisis de Chicago y también Presidente de la Asociación Psicoanalítica Americana. En 1959 publicó un artículo donde identificaba a la introspección y la empatía como ingredientes esenciales de la observación psicoanalítica. Continuó el desarrollo de un cuerpo de teoría conocido como Psicología del Yo (Kohut, 1971, 1977, 1978, 1984), utilizado por muchos terapeutas psicoanalíticos (Lachman, 2001). La empatía y el reconocer lo que el paciente está sintiendo forman una parte muy importante del tratamiento. Los pacientes con rasgos de personalidad narcisista, fármacodependencia o diferentes clases de psicosis, que sufren de depresión, sensación de vacio, carencia de autoestima o dificultades en su vida social y sexual no pueden ser tratados con el encuadre clásico. Todas las psicopatologías severas logran buenos índices de recuperación por medio de la psicoterapia con arte.

Kohut desarrolló su teoría después de observar que algunas personas con rasgos narcisistas no respondían al análisis clásico, sus 'Yos' internos, están formulando el concepto de falta de 'auto-cohesión', o consolidación. Desde el punto de vista de Kohut, la falla de empatía de parte de las personas que le dan cuidado en los primeros meses de vida al bebé es la causa principal de los desórdenes de la personalidad narcisista. Y es a través de la respuesta empática en la relación terapéutica que la cura puede ser lograda (Lachman, 2001, p. 68).

$\mathrm{El}$ arte es un medio que permite al paciente crear y ser observado por otro; a medida que el sujeto crea, los otros o él otro son objetos separados de sí mismo. Este aspecto contribuye a la individuación del paciente, a la superación de sus anhelos narcisistas arcaicos e infantiles. "Es muy importante que a través del proceso de reflejo los terapeutas sostengan la promesa de aprobación última para un real cumplimiento de una aprobación real" (Lachman, 2001, p. 70). 
La relación interpersonal dentro del encuadre terapéutico debe estar encaminada a ser neutral, considerando que el paciente necesita de ella. Así sea un esquizofrénico, esta relación tendrá significados muy especiales y puntuales para ese paciente. "El encuadre terapéutico con pacientes severamente perturbados debe ser una genuina relación terapéutica, no una técnica que simule transferencia. El terapeuta que logra éxitos terapéuticos con estos pacientes es honesto, cálido, y activo" (Spaniol, 2003, pp. 286-289), lo que no quiere decir directivo.

Cada una de las comunicaciones del paciente tiene un significado importante; por irracional que parezca siempre están teñidas de esperanza o de fantasías que desearía sean realidad, también de negaciones debido a los fracasos frecuentes en diferentes situaciones que son suficientes para una desesperanza aprendida. Con Freud aprendimos a buscar el sentido del inconsciente y el sentido afectivo, es decir, las fallas o aciertos en el afecto, vías que son los canales más seguros para sanar pero también para enfermar psicológicamente. El lenguaje es generalmente muy intelectual y magníficamente tiene el poder de negar, racionalizar y desplazar.

Considerando la teoría y reconociendo que es válida, este trabajo se esforzó por considerar todos los aspectos de la postura de Freud y de los psicoanalistas que han aportado a su desarrollo y continuación. En este trabajo psicoterapéutico se estableció un encuadre en el cual la figura femenina fue un objeto que proveyó holding a los pacientes, se dieron regresiones a la etapa oral y anal del desarrollo psicosexual. Un ejemplo de esta forma terapéutica fue permitirles fumar en el descanso de la terapia y proveerles refrigerio dentro del reciento de terapia. En el trabajo de arte también se dieron proyecciones referentes a esta etapa, dibujos de fijaciones orales que no es posible materializar en palabras.

En los trabajos de arte de casi todos los pacientes había una ańoranza por regresar a la casa paterna aunque los padres no los visitaran nunca en la clínica, ni se entendieran en ningún sentido de su situación. Podríamos afirmar que generalmente estas figuras son tan importantes para todos los seres humanos que siempre hay una disculpa a la situación, aunque fluctúe entre el amor y el odio. Sin embargo, hay 
pacientes que no logran reconciliarse con estas figuras y permanecen en un profundo dolor y resentimiento debido a la severidad de los traumas y, por lo tanto, tienen muy poca capacidad de insight y elaboración.

En la actualidad la terapia que utiliza el arte como facilitador y potencializador del proceso psicoterapéutico no es usada solamente en pacientes psiquiátricos, sino que es practicada en diferentes psicopatologías y en la recuperación de enfermedades físicas y terminales, debido al amplio margen de recuperación y alivio que ofrece a diferentes pacientes.

\section{Los valores del terapeuta}

Los valores del terapeuta cobran una importancia vital en el tratamiento. El valor fundamental del profesional debe ser el crecimiento y desarrollo de la personalidad del paciente, el apoyo que se le presta para que pueda adquirir autonomía y autoestima, cualidades del Yo que le permitirán satisfacer sus necesidades sin hacerse dańo él mismo ni dañar al otro. Fromm Reichmann afirma que la conciencia que tenga el terapeuta de sus propios valores, de las convenciones a las que el paciente está aún sometido, puede ser la única clave de un trabajo psicoterapéutico satisfactorio con el paciente psicótico, o puede facilitar en gran medida el tratamiento con un neurótico. "Finalmente Freud dice que puede llamarse psicoanálisis a toda ciencia y terapéutica que acepte sus doctrinas sobre el inconsciente, sobre la transferencia, la resistencia y sobre la sexualidad infantil" (Fromm Reichmann, 1978, p. 19).

Este trabajo de psicoterapia dinámica y arte no fue un psicoanálisis tradicional pero conservó los aspectos fundamentales planteados por Freud para la cura. La investigación se realizó llevando a cabo el encuadre expuesto.

\section{La transferencia}

Los conceptos intrínsicos del psicoanálisis freudiano y de la terapia analítica de Jung han influido en las aproximaciones de la terapia de arte dinámica; esto incluye la transferencia como uno de los aspectos 
básicos en el tratamiento analítico. Desde el punto de vista de la función de la cura, la transferencia es catalogada por Freud de manera muy explícita como uno de los obstáculos mayores al recuerdo del material reprimido. Pero también su aparición es señalada como generalizada: "podemos estar seguros de que la encontraremos en todo análisis relativamente serio" (Laplanche \& Pontalis, 1973, p. 405). El encuadre modificado permitió un desarrollo de transferencia en todos los pacientes con diferencias en el tiempo debido a las diferencias individuales de cada paciente. Los pacientes lograron en este trabajo psicoterapéutico con arte y con un encuadre modificado el desarrollo de una transferencia positiva que les permitió expresar experiencias muy primitivas, con gran necesidad de catarsis y elaboración. Además de la palabra, cualidad única del ser humano que no es posible ignorar, la técnica de arte principal fue la pintura en la psicoterapia de grupo. Como técnicas auxiliares se usaron la relajación y la música por considerarlas formas de potencializar la intervención por poseer aspectos emocionales profundos e inherentes al ser humano. La escritura complementó el dibujo.

\section{La relajación}

Se usó la relajación porque es una forma de contacto interno, descanso, tranquilidad y conciencia de sí mismo, es un facilitador de soltar la armadura muscular. El cuerpo nos sirve para negar o bloquear impulsos. Las defensas del carácter son manifestaciones en la estructura física del cuerpo. Cuando la persona se relaja baja la tensión, siente bienestar, toma conciencia de todas las partes de su cuerpo que tensiona y relaja simultáneamente; de esta forma se da cuenta del beneficio y de cómo puede manejar los estímulos internos y externos, y disminuir los niveles de ansiedad. La relajación permite también que fluyan pensamientos y sentimientos olvidados, es decir, reprimidos. La relajación del diván freudiano es similar a la relajación que se realizó en este trabajo de investigación encontrando que es beneficiosa para pacientes psicóticos y neuróticos. El paciente psicótico necesita un puente con la realidad exterior en la figura del terapeuta; por ese motivo el tiempo de relajación 
fue corto, de un máximo de veinte minutos para un tiempo total de tres horas en la psicoterapia de grupo.

En esta investigación se utilizó la relajación por considerarla un preámbulo importante para crear una atmósfera de tranquilidad y disminución de la tensión. El paciente psiquiátrico maneja permanentemente altos niveles de estrés y ansiedad. La relajación llevó a los pacientes a bajar la ansiedad y lograr menor tensión para iniciar el trabajo terapéutico.

Las raíces de un enfoque del cuerpo están claramente establecidas en los escritos de Freud, pero fue Reich quien delineó una psicoterapia orientada al cuerpo y quien es grandemente responsable de la tradición del cuerpo en psicoterapia. A través de su trabajo clínico de investigación Reich provee una base sólida para el movimiento más allá de las limitaciones del análisis freudiano. Varios de los estudiantes de Reich llevaron la tradición con gran creatividad e innovación en la teoría y la técnica. La tradición incluye el trabajo de Káiser, la terapia Gestalt de Perls, la ergonomía de Baker, la bioenergética de Lowen y Pierrakos, la psicoterapia organismica de Brown y el trabajo Raíz de Kelley (Smith, 1985).

\section{La música}

La música fue una técnica para facilitar la expresión de sentimientos. Los pacientes gravemente perturbados están bloqueados para las sensaciones emocionales que produce la música. La coraza de la que se han revestido para sobrevivir al dolor del abandono y la frustración desde la más tierna infancia, no les permite identificarse ni sentir una música que pueda ser solaz para el alma. Por eso la música permitió que el grupo de pacientes empezara a sentir a través de la música.

El desarrollo del conocimiento científico del funcionamiento del espíritu humano constituye el juego epistemológico esencial de las ciencias del conocimiento, se trata nada menos que de comprender cómo una estructura material que llamamos cerebro sostiene procesos aparentemente inmateriales que llamamos pensamiento (Mijolla, 1983, p. 18). 
Este autor hace referencia a la complejidad de la creación y comprensión de la música. La riqueza de la música responde ciertamente a una competencia auditiva que es exclusiva de la especie humana; la estructura de esta competencia tiene que tomar una forma indispensable, la de las dimensiones afectivas y existenciales que el ser humano experimenta con la música.

La música juega un papel de complejidad muy grande, desde la música misma y desde el aspecto psicoanalítico de la música, que expondremos en forma muy breve. Freud en Más allá del principio del placer propone la existencia de una pulsión de perfección que se posa en el desarrollo más elevado, más complejo, asimilando a Eros y que complica la vida. Otros aspectos de ese Eros son abordados y estudiados por Freud en diferentes niveles de conceptualización.

La música puede situarse como una investidura libidinal y de contenidos del inconsciente en el autor, que pueden ser evacuados y que llegan a un receptor. Una determinada música agrada, emociona, puede ser indiferente o desagradar al que la escucha. Es el efecto del afecto del que nos habló Freud en su estética refiriéndose al arte, ese afecto o gusto es particular; si gusta mueve infinidad de sentimientos en la persona que la escucha. Como sensación y sentimiento es aún más potente que la pintura, y es en ese afecto que el arte musical es terapéutico. Toda la música no impacta a un ser humano, pero hay tipos de música que permiten a todas las personas entrar en un estado tranquilizador, relajante, emotivo y reflexivo. También determinados tipos de música permiten la expresión de sentimientos de rabia y sirven para evacuar diferentes sentimientos negativos.

Como la pintura o el teatro, la música, sea creada, tocada o escuchada, tiene un efecto terapéutico debido a que desencadena múltiples emociones, estados de tranquilidad e identificaciones en el receptor.

Los fantasmas prehistóricos juegan igualmente en todo auditorio de música, recuerdos, sueños ancianos, por ejemplo recuerdos de la abuela tocando el piano, del tío tocando una romanza a la hora de la comida, o amorosos suspiros bajo un fondo sonoro (De Mijolla, 1982, p. 15). 
Es el caso para cualquier manifestación artística. La música es la identificación con una emoción de innumerables sentimientos tristes, alegres y melancólicos que están en una sinfonía o concierto.

Diferentes emociones y sentimientos llegan a lo más profundo del alma humana, al inconsciente, a los recuerdos de la vida, a las ańoranzas, a los fantasmas. La música como aplicación científica busca producir cambios en la vida afectiva de la persona, en la conducta social e individual del ser humano. Es el idioma universal del sentimiento; la música puede ser llamada esencia divina, sublime y humana.

Si se admite que la música tiene el poder de hacer resurgir la metáfora de los movimientos pulsionales y comprender que estos son toscos y originales, entonces es concebible que la escucha musical reactive la interiorización y capte el interno del alma con el flujo sonoro que viene de afuera haciendo un campo auditivo, una expansión sonora del Yo, un placer purificado, introyección al sentido mismo, nombrado por Ferenczi, encontrando las nociones tanto de odio como de libertad, lo mismo que en la gestión estética (Rosaloto, 1969, p. 163).

Considerando que la música es el abre bocas del alma y del espíritu, de los más sublimes sentimientos y de los más tristes y angustiosos recuerdos, no se podía dejar de introducir la música en el proceso de una psicoterapia que incluye el arte.

La música ella misma habla a los que se encantan, a los humanos que danzan con ella en un ardor colectivo. Más recientemente no conocemos las creaciones musicales especialmente hechas para cada uno pero hay algunas que llegan a cualquiera es el caso de 'Para Elisa' de Beethoven, se trata de hacer entender al otro lo que hay en el corazón (Berge, 1968, p. 9).

En este ejemplo se trata de una comunicación de los sentimientos al receptor y en el deseo del artista de comunicar su sentir, como comunicación de sí mismo. Así la música llega a los amantes que se comunican muchos sentimientos entre ellos mismos, de la misma forma al público y a la terapia, en la que los pacientes revuelven y 
afloran sentimientos como en una vasija agitada que puede ser próxima a rebotar todo tipo de sentimientos y añoranzas. Este trabajo de investigación quiso estudiar el avance que produce el arte en la aplicación de las ciencias psicológicas.

En una sesión de psicoterapia de grupo, después de que los pacientes habían consumido cocaína y una semana después de los efectos de la droga, se trabajó una técnica dirigida llamada Cómo romper la pared de la adicción a las sustancias psicoactivas. Durante la relajación se tocó la sexta sinfonía La Patética de Tchaikovsky, lo que llevó a varios pacientes a llorar y tomar una fuerte resolución para no volver a consumir. En una psicoterapia realizada con arte es imposible desconsiderar el valor terapéutico de la música. La pulsión de muerte establecida en pacientes psiquiátricos, psicóticos y fármacodependientes está considerablemente presente, pero los elementos de vida proporcionados mediante el arte en forma de música, pintura y narrativa abrieron posibilidades para ellos. "El ritmo adquiere un valor de causa y consecuencia porque al mismo tiempo que transforma el sonido en música, permite elaborar e identificar su naturaleza" (Cain, 1982, p. 134).

Las metáforas energéticas relacionadas con el estado de ánimo que siente el sujeto en determinado momento como resultado del placer por un determinado ritmo o para el compositor de la creación y la escucha marcan un hito de sublimación. La belleza en lo analizado, en la expresión cuantitativa de afectos, sentimientos y estética que no sea vacía de sensaciones, es en realidad la música, porque una belleza puramente formal vacía de emociones nos sería concebible como música. Los afectos están de diferente manera ligados de manera lejana al masoquismo como recuerdo, ilusión e identificación.

\section{La pintura}

La pintura permite que la imagen trabajada en una sesión de psicoterapia quede grabada, el paciente puede recordar cómo se sentía cuando la realizó. La imagen gravada es un testimonio que se puede 
guardar, volver a mirar, retomar en un momento dado, pero también es particular porque no se ve de la misma forma después de un tiempo de realizado el trabajo; es este el caso del pintor profesional, del aficionado o del paciente. La pintura fue en esta investigación una forma muy positiva de contención, abreación e insight, y permitió a los pacientes y al terapeuta comprobar los logros, como testimonio de la evolución del proceso terapéutico, de la elaboración de su problemática, ayudando a la construcción de la autoestima.

Cuando se realiza un cierre con un paciente que ha durado dos ańos y medio realizando permanentemente trabajos de arte, este se encuentra con la sorpresa de algo que ha hecho, que ha logrado y que de alguna forma le parece increíble y a la vez fantástico en profundidad y progreso, y despierta sentimientos de toda índole, alegría, tristeza, sorpresa y, por qué no, dolor, del dolor que vivió pero que ha superado y que tiene que seguir elaborando.

La terapia de arte brinda al paciente la capacidad de entender su propio proceso dinámico y en decrecer su nivel de negación defensiva. En pacientes drogadictos y psicóticos la disminución de los mecanismos de defensa, escisión, identificación proyectiva generalmente disminuyen (Silverman, 1991, p. 93).

La pintura es una expresión abierta a innumerables aspectos que integran a la persona mediante el trabajo terapéutico que solamente con la palabra no puede ser logrado con pacientes gravemente perturbados, debido a que la comunicación verbal está bloqueada, el paciente no puede o no quiere hablar. La pintura permite la expresión del mundo interno que no podía ser expresado. El proceso artístico provee situaciones y espacios que anteriormente solo habían sido accesibles a los nińos, debido a que los terapeutas de niños, pensando en la dificultad del lenguaje y del incompleto desarrollo del pensamiento, usaron la técnica pictórica para facilitar el proceso. En este trabajo de psicoterapia con arte se observó cómo la pintura llegó a ser una forma de expresión que llevó a los pacientes a estadios muy tempranos del desarrollo de la personalidad, a estadios de las relaciones objétales tempranas. 
Bion establece en el prefacio de su libro Segundos Pensamientos cómo la memoria nace y se adecúa a la experiencia sensorial. La experiencia nos muestra que las imágenes que han impactado a un sujeto quedan gravadas en el inconsciente desde la más tierna infancia.

La expresión de arte puede ayudar a hacer puente entre el preconsciente, el inconsciente y el consciente de un evento traumático y tensionante, facilitando la creación de una narrativa a través de la cual la persona puede explorar el aparato topográfico. Las actividades de arte, en este sentido, pueden ayudar a proyectar las sensaciones y los sentimientos. En el aspecto de las sensaciones el individuo no ha desarrollado el lenguaje verbal. Finalmente, la terapia de arte puede ser usada para tocar la respuesta de relajación del cuerpo. El dibujar facilita los reportes emocionalmente cargados de varias maneras: reduce de la ansiedad, ayuda al paciente a sentirse confortable con el terapeuta, e incrementa la memoria organizando asociaciones para narrarlas promoviendo el interno para encontrar más aspectos. Malchiodi (1997, 2001) observó al trabajar con niños de hogares violentos que la actividad de arte tenía una influencia suavizante e hipnótica, y que los niños traumatizados eran atraídos naturalmente a esta actividad cuando estaban ansiosos o sufriendo de estrés postraumático.

En un día no muy lejano, a través del uso del scan del cerebro y otras tecnologías que aportan las neurociencias, se podrá tener un entendimiento más claro de cómo usar exactamente la terapia de arte para obtener la respuesta de relajación en pacientes de todas las edades que hayan sufrido intensos traumas y estrés. A nivel de las relaciones objetales tempranas, una experiencia interna e inconsciente no puede ser alcanzada solamente por la memoria debido a que las experiencias sensoriales son infra verbales, esto es, antes del lenguaje.

A través del arte un paciente puede expresar, controlar y empezar a elaborar, simbólicamente, experiencias de incapacidad, dolor, constricción o inadecuación. El arte constituye una forma muy interesante y gráfica de observar el proceso de un paciente y cómo expresa el sentir de una enfermedad psicótica. 
Una paciente de veinte años diagnosticada con esquizofrenia paranoide y hospitalizada en la clínica inició el tratamiento psicológico con arte. Sus dibujos mostraron cómo fue elaborando y desarrollando capacidades de conocimiento y autovigilancia de sus estados agresivos, de su deseo de relacionarse, de socializar y de compartir con otros seres humanos. También mostraron cómo se sentía antes del proceso psicoterapéutico y después, y cómo en el inconsciente había una construcción simétrica que le permitía no desintegrarse. Los dibujos mostraron también el peso que vivía en su casa, representado mediante un techo muy bajo con aspecto de plomo; casi siempre esa casa estaba representada en sus dibujos como un único signo de protección (ver Figura 5).

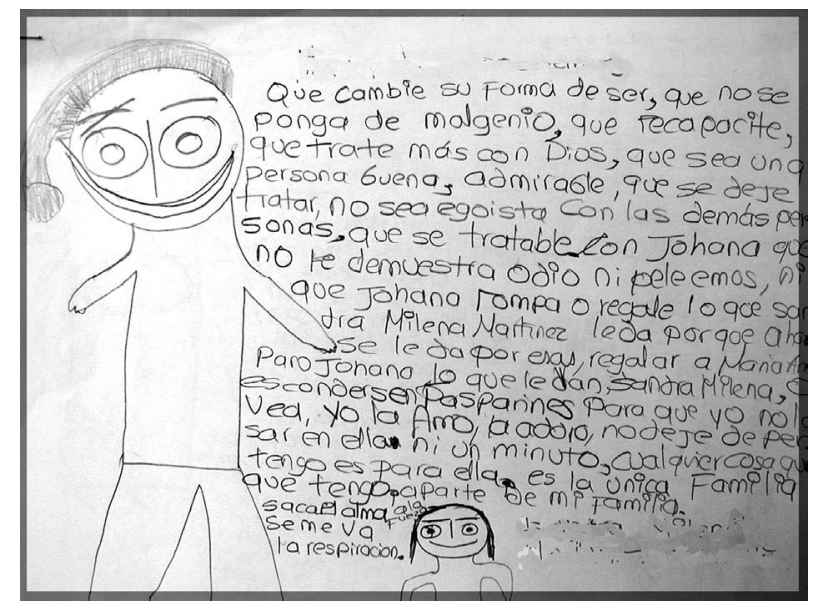

Figura 2. Proyecciones escritas de sus deseos y conflictos.

En el dibujo de la Figura 2, la paciente muestra claramente los síntomas de su enfermedad. Durante un año aproximadamente ella escribe interminables cartas que trabajamos en la terapia individual. Las cartas se refieren a sus relaciones familiares, especialmente con la madre, el dolor por el abandono del padre y el conflicto con su familia 
extensa. Los dibujos son similares al de la Figura 2 y casi siempre solamente escribía.

En la segunda etapa del tratamiento hace inferencias importantes relacionadas con su mundo interno. Uno de los dibujos más expresivos de esa etapa es el que ella titula La vida (Figura 3), donde escribe luz y oscuridad. Parecería que la paciente empieza a ver elementos de luz a través del proceso psicoterapéutico y relaciona la vida con la luz; se puede inferir también que la oscuridad es su enfermedad.

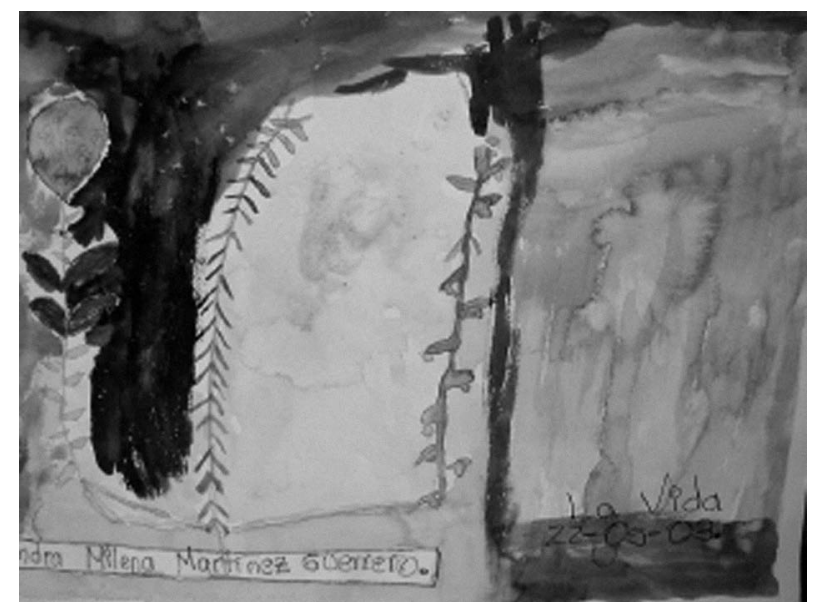

Figura 3. La vida.

En la Figura 4 la paciente expresa su deseo de socializar, tener amigos y realizar actividades en grupo y al aire libre. Pinta varias escenas de niños realizando diferentes actividades. En el centro del dibujo pinta una gatica y escribe una gatica traviesa y sexual, se pinta ella con una amiga especial y también elevando una cometa. Hay en este dibujo varias proyecciones importantes, la sexualidad está presente, su identificación y el deseo de realizar actividades sociales y compartir con amigos. 


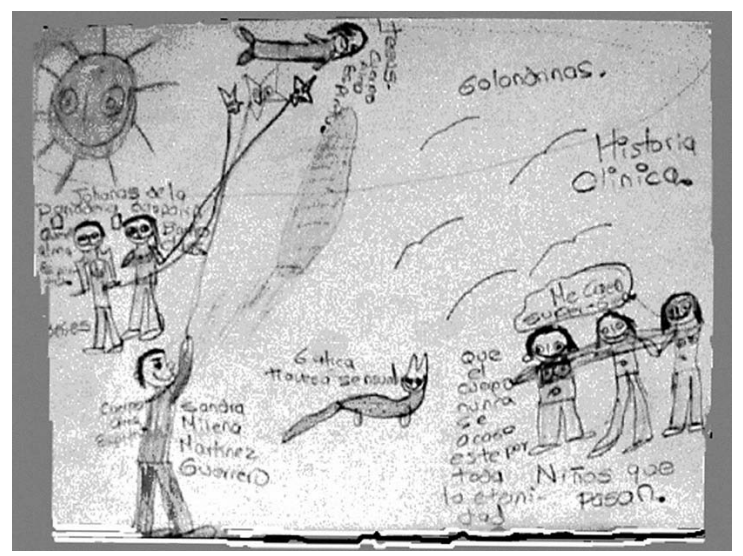

Figura 4. Niños que pasean.

En la Figura 5 la paciente manifiesta que el ábaco significa la falta de movilidad y libertad que ella tiene. Expresa que se siente metida en cada cuadro, del que le es muy difícil salir, pero que finalmente lo logra. En la parte inferior dibuja su casa con el techo rojo, las paredes negras y enmarcada en un rombo de metal; al fondo a la derecha dibuja otra casa que representa la clínica.

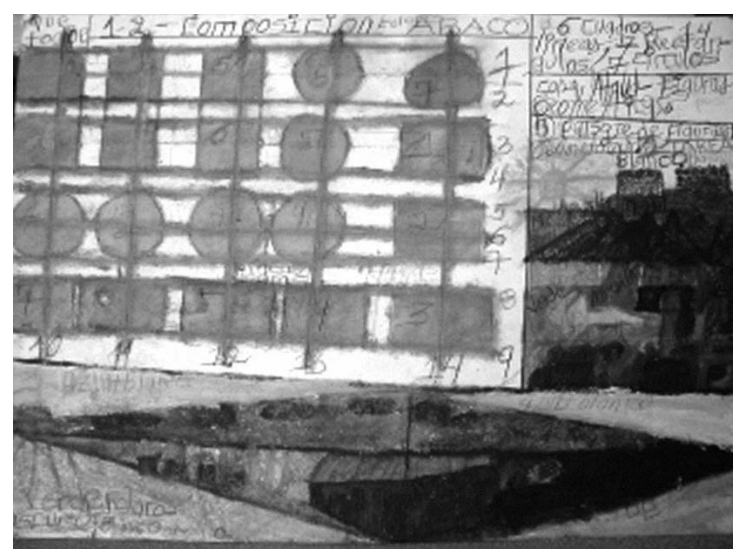

Figura 5. Composición Ábaco. 


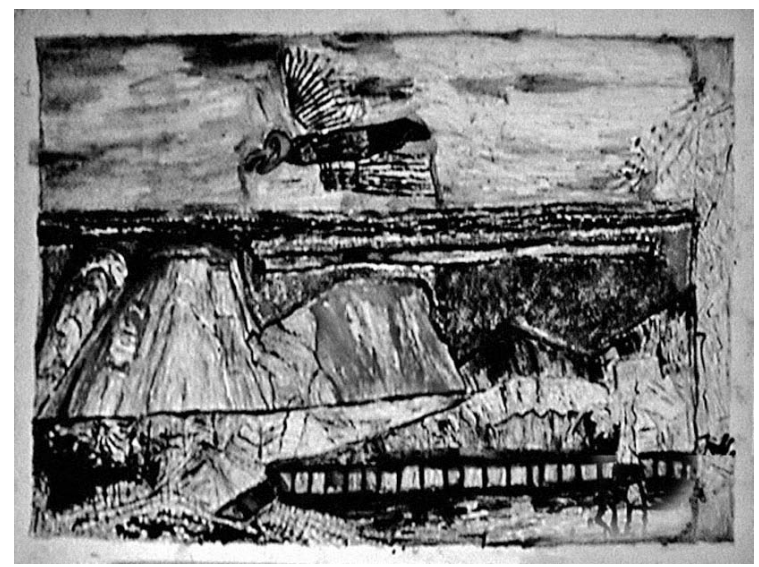

Figura 6. El pájaro sin rumbo.

La Figura 6 Pájaro sin rumbo es realizada al final del proceso psicoterapéutico, cuando la paciente ya estaba en tratamiento ambulatorio. La paciente escribe: ese pájaro vuela buscando un sitio especifico dónde estar. Dice: soy yo misma. El pájaro va a las montańas, vuela, atraviesa volcanes y valles, y no sabe a dónde ir. En la parte inferior está nuevamente su casa, un camino y unos arbustos.

Winnicott, en su experiencia terapéutica con niños, muestra cómo los sentimientos del niño abandonado, del regresivo paciente adicto y psicótico, están acompańados de miedo, venganza, desconfianza y carencia de apoyo, por esto están tan necesitados de holding. El trabajo de arte pictórico representa una proyección gráfica de los conflictos internos del paciente. Estos trabajos tienen características de las técnicas proyectivas y acceden a la creación propia del individuo. La capacidad crítica del Superyo está bloqueada, el Yo disminuido y desorientado. Esta situación no permite un acceso fructífero a la comunicación verbal del individuo, y es así como el arte pictórico se convierte en un medio facilitador y creativo del proceso psicoterapéutico. Winnicott establece la importancia del juego y el arte como medios terapéuticos y de desarrollo emocional del niño, con los cuales 
se puede facilitar el proceso del paciente adulto. Este trabajo consideró el paradigma de Winnicott de individuación, objeto de transición y vínculo, a través del proceso terapéutico, el encuadre terapéutico proveyó holding al paciente.

Freud en sus investigaciones estableció las similitudes y diferencias entre sueńo y arte. Es por eso que podemos trabajar la psicoterapia dinámica que implementa el arte. "El arte, como los sueños, son un 'camino real al inconsciente'” (Freud, 1981, pp. 2063-2064). En esta investigación, además de la palabra, la técnica de arte principal fue la pintura en la psicoterapia de grupo. La técnica de pintura se realizó en casi todas las sesiones de grupo, y además los participantes debían escribir una corta historia referente a la pintura para completar el proceso de expresión. Esto permitió que quedaran claros los significados de los dibujos que, si bien algunos tenían aspectos muy claros, otros se escapaban a la comprensión de lo que quería decir el paciente. En las sesiones de terapia individual algunos pacientes deseaban comunicar aspectos que no habían expresado en la terapia de grupo por ser muy íntimos.

El reconocer la función creativa e integrativa del juego y el arte nos permite ver la realidad interna y externa del sujeto. La proyección expresada en un dibujo de arte pictórico terapéutico por un paciente permite al terapeuta comprobar la teoría y, al mismo tiempo, ver el estado interno del paciente continuando con el proceso psicoterapéutico, como una linterna que permite transitar por el oscuro inconsciente del paciente. Al paciente experimenta admiración y clarificación de aspectos que no comprendía, y que puede materializar y potencializar mientras avanza en el proceso terapéutico.

El proceso artístico provee al paciente más libertad y facilidad para comunicarse. La pintura muestra cómo el paciente lucha para organizar material suficiente para empezar a comunicarse. Con pacientes gravemente perturbados la terapia se inicia generalmente de forma no verbal, la simbolización del material es altamente primitiva. Durante el proceso la evolución de los trabajos de arte es muy significativa. Kohut 
(1971) enfatiza un déficit en la organización del Yo en pacientes gravemente perturbados; así la terapia que involucra el arte aparece entonces como un medio adecuado para estos pacientes. Hay evidencia de que las imágenes tienen un impacto significativo en la mente y en el cuerpo, es decir, la mente afecta al cuerpo. Las imágenes pueden crear sensaciones de bienestar, desagrado, placer o temor. El sentido común nos dice que las imágenes tienen un impacto sobre cómo nos sentimos y reaccionamos.

En este trabajo psicoterapéutico utilizando el arte pictórico se observaron insights no logrados a través del lenguaje lineal verbal. Este es uno de los aspectos más importantes logrados en esta investigación. Las imágenes graficas son comunicación, consciente, preconsciente, e inconsciente, en el caso del artista, y de los pacientes, los pensamientos encapsulados y no diferenciados son expresados generalmente en forma simbólica.

\section{El simbolismo y la terapia de arte}

La imagen de la Figura 7 fue realizada por un paciente diagnosticado psiquiátricamente con esquizofrenia paranoide. Él expresa en la pintura el deseo de regresar a su casa en el campo y de tener un carro para transportarse. Esta expresión simbólica es llana y primitiva.

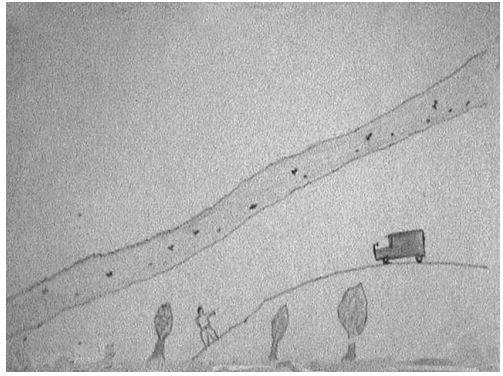

Figura 7. Añoranza.

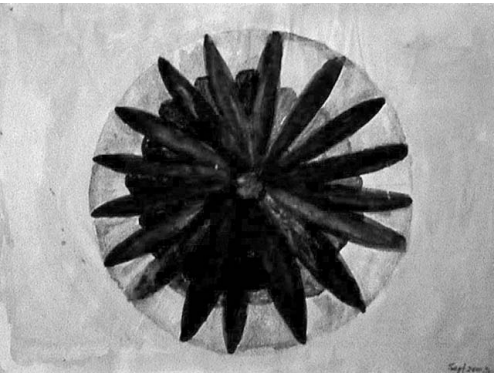

Figura 8. El temor de ir al fondo. 
Después de doce meses de tratamiento el paciente evoluciona en su expresión simbólica y en su capacidad de insight. Realiza una serie de trabajos en los cuales simboliza el deseo de ir al inconsciente. Los dibujos y escritos manifiestan el temor de ir al fondo de su persona y comprender qué ha pasado con él. Hace dibujos similares al de la Figura 8 y los titula con frases que tienen el mismo sentido. Se vislumbra ya en el paciente una capacidad de mirar en su interior. También lo expresa con frases que escribía frecuentemente como ir más allá o ir de la oscuridad a la luz. Se puede inferir que se ha dado un proceso de abreación y capacidad de insight.

Aproximadamente a la mitad del proceso psicoterapéutico este paciente realiza varios dibujos de árboles a partir de una mancha de tinta y escribe textos alusivos a la estructuración de su persona (ver Figura 9). Escribe: un árbol veterano bastante frondoso, con sus raices bien profundas, bien enraizado y plantado y bastante ramificado. En la Figura 10 escribe un árbol fuerte, frondoso, crecido, grande y fuerte. Proyección de sus deseos, algo de lo que ha logrado en el proceso terapéutico, expresión de una necesidad de verse y sentirse, y quizás de haber superado aspectos de su persona.

\section{Los símbolos}

Los símbolos son exclusivos del ser humano. En la enfermedad mental el proceso simbólico esta deteriorado porque el sujeto ha cambiado su realidad por una realidad amorfa, sin sentido, no coherente con los cánones establecidos. El psicótico simboliza lo que ve y siente su mente escindida y regida por el proceso primario de pensamiento. Por eso la psicoterapia que involucra el arte ayuda a establecer el proceso simbólico. 


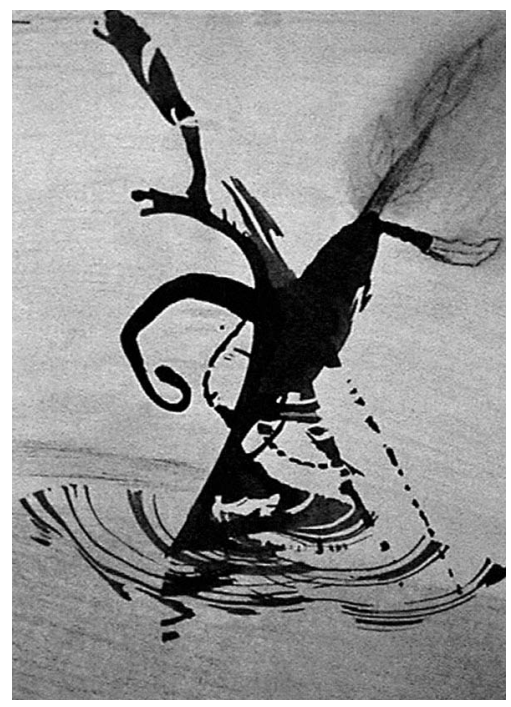

Figura 9. Un árbol frondoso.

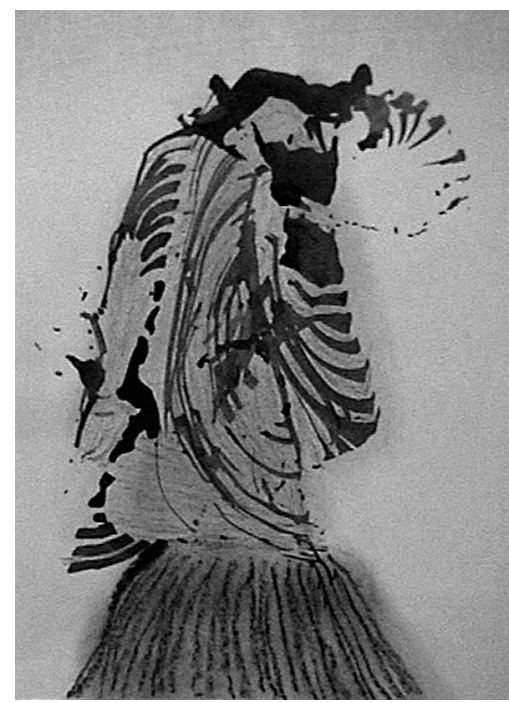

Figura 10. Un árbol fuerte.

A la relación constante entre el elemento del sueño y su traducción le damos el nombre de relación simbólica puesto que el elemento mismo viene a constituir un símbolo de la idea onírica inconsciente que a él corresponde. Con la representación simbólica se enlazan interesantísimas cuestiones relacionadas con el simbolismo en el sueño. Estos símbolos tienen una relación con la expresión, no solo de los sueños, sino también de la expresión artística, como también Freud resaltó y estableció las diferencias y similitudes entre el sueño y la obra de arte.

Todas las analogías evocadas a propósito del simbolismo de los sueños nos permitirán formarnos una idea de aquellas especiales características del psicoanálisis que lo convierten en una disciplina de interés general, cosa que no sucede en la Psicología ni en la Psiquiatría (Freud, 1981, pp. 22-25). 
Se refiere Freud a la inquietud general del sueño y su simbolismo, y a cómo hay en el sueño símbolos universales que son representados por la relación con el inconsciente colectivo y cómo el común de las gentes se interesa en el significado de los sueños desde la antigüedad. Aún antes de descubrir el inconsciente los relatos bíblicos hablan del significado de los sueños. Parecería que hay en el contenido latente del sueño un saber propio y particular de la persona, el cual no es fácil pero sí factible descifrar. En la intervención psicoterapéutica con arte se encuentran significados y significantes generales y particulares del simbolismo de los seres humanos, muy particulares de la historia del individuo y universales, muy puntuales de las fijaciones, traumas y temores de cada individuo.

La labor psicoanalítica nos pone en relación con la gran cantidad de otras ciencias mentales tales como la mitología, la lingüística, el folklore, la psicología de los pueblos, las religiones, el arte y todas las ciencias cuyas investigaciones pueden proporcionarnos los más preciados datos" (Freud, 1981, pp. 22-26).

Un buen ejemplo del simbolismo y de lo gravado en el inconsciente son las pinturas expuestas en este artículo que nos permiten ver los postulados de Winnicott respecto a la necesidad de la función de holding y las consecuencias de su carencia. Winnicott nos planteó la importancia de ser conocido, que significa sentirse integrado. Dice:

El pequeño que no haya dispuesto de una persona que recoja sus 'pedacitos' empieza con su propia tarea de auto integración pero si esta falla se enfrenta a la enfermedad mental. La terapia dinámica y el arte son caminos para unir los pedacitos de esa personalidad fracturada (Winnicott, 1971).

Agrega Winnicott que la estructuración de las experiencias de realidad va surgiendo de la diferenciación de los tres espacios psíquicos (subjetivo, transicional y objetivo), la realidad surge por la sobrevivencia del sujeto. El terapeuta ayuda a que el paciente reemplace racionalizaciones muy distorsionadas por otras menos deformadas que 
integran el diálogo y el afecto. El arte se convierte en un objeto transicional entre paciente y terapeuta.

Esta disociación cede el paso a la relación ambivalente con la madre que nos describe Sterba, la preocupación por la madre y la ansiedad por lo que puede haberle hecho y seguir haciéndole con sus impulsos sádicos cargados de envidia, celos y rivalidad (Sterba, 1974). La posición depresiva corresponde a una mayor integración del Yo y de los objetos y a la capacidad incipiente de reparar el daño causado al objeto. Junto con esta integración empieza a desarrollarse el juicio de realidad, la formación de símbolos y la capacidad de discernir entre el mundo interno y el mundo externo.

El terapeuta ayuda a que el paciente reemplace racionalizaciones muy distorsionadas por otras menos deformadas que integran el diálogo y el afecto. El arte se convierte en un objeto transicional entre paciente y terapeuta. Bowlby (1980) opina que la base del desarrollo humano es una sensación de confianza en la disponibilidad de las personas con las que mantenemos lazos afectivos, confianza que se desarrolla lentamente a través de la infancia, la niñez y la adolescencia. Dicha disponibilidad consiste en una respuesta constante a nuestras necesidades afectivas: caricias, comprensión, compañía, comunicación y atención.

Algunos de los autores citados anteriormente, entre otros, dieron origen a lo que se ha conocido como la Teoría de las Relaciones Objetales en psicoanálisis. Esta teoría centra la exploración de la relación entre los objetos internos y los modos en que la persona mantiene estas relaciones inconscientemente al enfrentarse con las vivencias concretas.

Las teorías de Bion y Klein para el desarrollo oral han sido confirmadas por la expresión pictórica de esta investigación. En Mujer de senos grandes (ver Figura 11), dibujo realizado por un paciente fármacodependiente después de doce meses de intervención psicoterapéutica con arte, se expresan fijaciones orales. A partir de una mancha de tinta el paciente estructura la imagen de una mujer y escribe: es una bella mujer con los senos muy grandes y un seno desfigurado. El paciente es un joven de 25 ańos, soltero y proveniente de una familia de trabajadores 
artesanos. Fue huérfano de madre a la edad de doce años, hecho que lo hizo sentirse abandonado debido a que el padre viajó a otra ciudad en busca de trabajo. El niño se quedó al cuidado de una tía que no pudo proveerle el apoyo necesario para superar el duelo de la madre y el abandono del padre. Empezó el consumo de psicofármacos con marihuana a los doce años, poco después de la muerte de su madre, y siguió con alcohol, cocaína y bazuco. En la familia hay otro hermano fármacodependiente. En este paciente se agravaron sus fijaciones y traumas de la etapa oral con la muerte de la madre.

\section{Análisis del dibujo por los pacientes en psicoterapia dinámica de grupo que implementa el arte}

A partir del dibujo en la terapia de grupo los participantes expusieron las sensaciones y sentimientos que despertó el dibujo del paciente en cada uno de ellos. La mancha de tinta es lo que se revela en negro, lo estructurado en gris es la composición proyectiva del paciente.

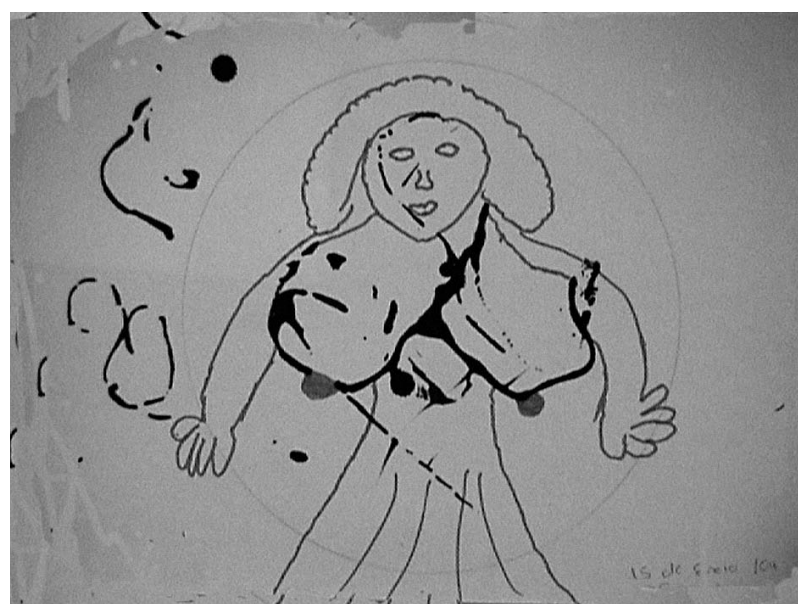

Figura 11. Mujer de senos grandes. 
El paciente escribe: Es una bella mujer de senos demasiado grandes y cintura muy pequeña, con abundante cabellera, el rostro un poco cortado y su seno izquierdo desfigurado.

Terapeuta: ¿Qué cree ha desfigurado el seno?

Paciente: No sé.

Terapeuta: ¿Qué cortó el rostro?

Paciente: Posiblemente una pelea.

Terapeuta: ¿Qué ven ustedes en que DT haya estructurado una mujer de senos muy grandes y uno desfigurado?

Pacientes: La expresión de la maternidad. Le hace falta el afecto de la madre. Está necesitado de amor. Le hace falta una mujer. Los senos le servirian de almohada. El dibujo expresa la belleza de la maternidad. Siente la ausencia de la madre. Está necesitado de amor. Desea una mujer de senos grandes que son ricos para amamantar. Desea apoyar la cabeza en los senos de una mujer.

Un paciente: El dibujo para mi representa la leche y la miel.

Terapeuta: ¿Qué significaría la leche?

Un paciente: El alimento para la vida.

Terapeuta: ¿Y la miel?

Un paciente: Es la esencia y dulzura de la vida.

Terapeuta: ¿Emocionalmente qué nace ahi?

Un paciente: El amor y el afecto.

La frase, con un seno desfigurado, deformado, muestra la postura kleiniana en la cual hay una ambivalencia por haber dañado el objeto seno. Pero lógicamente no hay saber consciente de qué dañó el seno. La frase una mujer de senos muy grandes expresada por el paciente, se puede atribuir a la necesidad de holding, de amor objetal temprano, que puede ser reparado en parte a través del proceso terapéutico y en la continuidad de la vida afectiva con un objeto amoroso. Dentro del simbolismo de las relaciones objetales hay una sensación de carencia aparte de los sentimientos de culpa. El sujeto trabaja de forma simbólica y explicita esa situación primaria de las relaciones objetales tempranas; es una manifestación de la teoría en la práctica de la terapéutica de arte. 
El concepto de reparación introducido por Klein en Fases de la Angustia Infantil (1929), se refleja en un trabajo de arte psicoterapéutico. También se refleja la fijación en la segunda etapa oral del desarrollo psicosexual en forma de adicción a sustancias psicoactivas.

Este trabajo impactó las relaciones objetales tempranas, donde el Yo se dirige a la posibilidad de reparar el seno (objeto amado y dañado por los instintos agresivos del bebé), a través de la integración de los aspectos buenos y malos, el amor y el odio, con la integración en la fase depresiva. Es la respuesta de un paciente referente a procesos vitales, frente a situaciones de cambio, y de integrar los aspectos positivos y negativos de la vida, como debe ocurrir con todo ser humano.

Este trabajo psicoterapéutico con arte pictórico permitió ver que en la psiquis del ser humano encontramos imágenes gravadas desde la más tierna infancia, es decir, desde las relaciones objetales tempranas, que son manifestadas como símbolos de algo real, explicable desde el psicoanálisis y que el arte terapéutico pictórico permite expresar en imágenes.

En casi todos los pacientes gravemente perturbados el proceso simbólico está deteriorado. En este trabajo se fue desarrollando este proceso simbólico con la práctica de crear imágenes, proyectarlas e interpretarlas. El persistente trabajo de hacer imágenes visuales en las sesiones de terapia de arte hace desarrollar en los pacientes la habilidad para simbolizar, deteriorada por la enfermedad mental que ha afectado al Yo y por la pérdida o problemas con la realidad que caracterizan a la esquizofrenia. Para Beres (1965), esto es una pérdida de la capacidad para reconocer diferencias entre el objeto real y su representación. Las imágenes visuales facilitan la simbolización.

La destreza y sensibilidad del terapeuta ayudan al paciente a iniciar su trabajo. La experiencia vivida fue que los pacientes incrementan su capacidad de pensar, de estructurar una idea y de materializarla, y la expresan con contenidos profundos del sí mismo, debido al proceso que el arte permite. De otra parte, puede retener el control de sus producciones e interpretaciones. 


\section{Las psicologías profundas valoran las imágenes internas}

Las psicologías profundas valoran las imágenes internas, hacen un llamado al artista en cada terapeuta de arte. La tarea de comprender la comunicación simbólica a través del arte es tan grande que estamos constantemente desafiando para encontrar nuevas y mejores formas para entender los mensajes que nuestros pacientes nos envían a través de sus imágenes. Las aproximaciones psicodinámicas, enraizadas en el trabajo de Freud y Yung, permanecen muy atractivas a muchos trabajadores de nuestro campo. Ellas son, sin embargo, solo una parte de la verdad para algunos y aún aversivas para otros.

\section{Desarrollo de las funciones psiconeurológicas logradas con la intervención}

\section{La capacidad de pensar}

La capacidad de pensar está bloqueada y deteriorada en estos pacientes debido a la incomunicación, a la falta de estímulos intelectuales, a la indiferencia de estos pacientes hacia ellos mismos, a la enfermedad en sí misma y a la inactividad causada por la enfermedad. Un comienzo de pensamiento se da en las sesiones iniciales. El uso creativo de la terapia de arte requiere un balance entre el proceso primario y secundario de pensamiento, puede aparecer un aspecto creativo y altamente simbólico. Generalmente el paciente al inicio de la sesión debe pensar, es decir, debe iniciar un proceso de reflexión para iniciar el trabajo de reconocimiento de sí mismo, de su problemática y de su entorno. Ese ejercicio necesita del proceso de pensamiento, entonces el paciente mismo dice o se dirige al terapeuta y expresa: ¿Cómo puedo yo desarrollar esa idea? Si bien ecomo en toda terapia hay un proceso de defensa esencial, de resistencia, en la terapia de arte se empieza a romper en el proceso de pensar y estructurar una idea que viene del interior del paciente. 
En los pacientes fármacodependientes las drogas han deteriorado el sistema nervioso, por lo tanto el pensamiento, el lenguaje y todas las funciones psiconeurológicas están afectadas. Al ingresar a terapia un paciente fármacodependiente no coordinaba las frases, y estas no eran coherentes en su estructura con lo que él quería comunicar. Él fue desarrollando el lenguaje y el pensamiento de forma normal. Su progreso fue tan evidente que todas las personas que lo conocían en la clínica, pacientes y terapeutas, estaban sorprendidas por su forma de expresar las ideas y él mismo estaba asombrado con el cambio.

Cuando se tiene al arte como medio terapéutico hay un desarrollo en la organización de las funciones neuropsicológicas de los pacientes que viven dentro de un terrorífico caos sin control. La capacidad de pensamiento acerca de ellos mismos parece separada del objeto y depende, ciertamente, del estadio del desarrollo de las relaciones objetales. Podemos decir que la terapia de arte ha ayudado a los pacientes en el desarrollo del lenguaje y del pensamiento, en la comprensión de las ideas y en la capacidad de asociar sus producciones con su historia. Se descubrió e incremento la creatividad, lo que contribuyó a establecer una capacidad de logro, autoestima y autonomía.

\section{Tiempo y espacio}

El concepto de tiempo y espacio es crucial en estos pacientes y es un área en la cual el arte también puede proveer un lenguaje. Los pacientes psicóticos padecen de una severa desorganización en el tiempo y el espacio, y una dificultad en la integridad corporal. Una pieza de trabajo pensado y contemplado es más fácilmente conectada por el paciente que no tiene la habilidad para centrar sus sentimientos. El proceso permitió romper ese embotamiento, empantanado, cenagoso, que no permite mover ni el externo ni el interno. Las ansiedades primarias en este nivel de funcionamiento tienen que ver con la potencial aniquilación del Yo, con una incapacidad para superar la sensación de inadecuación y muerte. El arte puede dar una extensión al Yo como 
capacidad de espejo de concretización para lograr actuar fuera del contexto enfermo. El terapeuta de arte debe ser consciente del mundo estático de estos pacientes y ayudarlos de forma no intrusiva a usar el trabajo de arte como continuidad y experiencia.

\section{Conclusiones}

El proceso psicoterapéutico permitió ver cambios favorables a diferentes niveles en los pacientes que fueron intervenidos. Al final de la terapia de arte los pacientes habían desarrollado mayor capacidad en su Yo observador, capacitándolos para proyectar imágenes más complejas de su problemática. Si bien al comienzo de la intervención las imágenes fueron infantiles y primitivas, con contenidos importantes pero muy intelectuales, después de un año de tratamiento las imágenes proyectadas fueron más estructuradas en relación a sus psicopatologías. Pudieron reconocer muchos aspectos de sus vidas de diferente forma, es decir, con aceptación, capacidad y deseo de llevar una vida diferente viendo un mundo menos hostil para ellos. Se observó una expresión de aceptación de la enfermedad y de cómo manejarla. Al finalizar el proceso se habían logrado aspectos importantes en cada paciente a nivel de sus relaciones interpersonales, su autoestima y su autonomía para el inicio de una nueva vida.

El arte les permitió ver su capacidad creativa, de logro, imaginaria y simbólica. Hubo una sensación de que son tenidos en cuenta como seres humanos y que pueden esperar tener una vida más útil y más realizada.

Las funciones neuropsicológicas se recuperaron e incrementaron con la intervención psicoterapéutica en todos los pacientes, aunque a diferente nivel en cada uno. El grado de compromiso fue directamente proporcional a los recursos del Yo.

Los pacientes que fueron intervenidos no tuvieron otro tipo de psicoterapia durante el tiempo de la investigación. Las conclusiones están dadas considerando que los cambios obtenidos están sujetos a 
diferentes verificaciones, como son la mejoría y la conducta al volver al núcleo familiar, donde el mismo ambiente puede ocasionar una recaída en los pacientes.

La medicación psiquiátrica fue disminuida en los pacientes con esquizofrenia paranoide a medida que la psicoterapia progresaba. Se observó también más participación en las diferentes actividades de la clínica, en la terapia de grupo y en la terapia individual, en todos los pacientes.

Se trabajó en permanente contacto con la psiquiatra que manejaba el Programa de Rehabilitación Integral (PRI). Ella afirma que se disminuyó la medicación a varios pacientes por observarlos menos ansiosos, menos agresivos y más participativos en todas las actividades del programa, también con una mejor presentación y cuidado personal.

Como última conclusión se puede establecer que hubo cambios positivos considerables en cada paciente respecto a cómo estaban al iniciarse el proceso psicoterapéutico. Este aspecto considera varias variables como el vínculo establecido durante el proceso entre paciente y terapeuta, la duración moderadamente larga del trabajo, la continuidad y las técnicas empleadas.

El trabajo de intervención psicoterapéutica con la familia es condición indispensable para el control y disminución de los síntomas en pacientes de todas las psicopatologías, y para mantener los niveles de funcionalidad, debido a que al salir el paciente al mismo contexto familiar y social posiblemente va a recaer debido a que encontrará la misma situación disfuncional que hará que se reactiven los síntomas de su enfermedad.

De otra parte, en la terapia de familia se genera un cambio de actitud hacia el paciente, debido a que hay una mayor comprensión clínica y emocional de lo que pasa con ese miembro del sistema familiar. Sin embargo, consideremos el postulado de Aristóteles: "las mismas causas en las mismas circunstancias producen siempre los mismos efectos". De todas formas en mayor o menor grado la terapia de familia ofrece algunos cambios positivos en el sistema. 
Un aspecto primordial para el avance en tener una familia más armónica y más sana afectiva y emocionalmente es la capacitación a padres y educadores como prevención al desarrollo de las diferentes psicopatológias severas.

Este trabajo abre posibilidades para próximas investigaciones que aportarán al conocimiento de psicólogos, psicoanalistas, médicos, psiquiatras, trabajadores sociales y educadores, como una innovación en la intervención teniendo el arte como facilitador y potencializador del proceso psicoterapéutico, aportando al beneficio de los seres humanos para un mejor vivir en este siglo que empieza y que hemos llamado: Psicología y Arte, Ciencia del Tercer Milenio.

\section{Referencias}

Ada, A. (1990). The projection of the inner group dynamics in drawing. Group Analysis, 23, 391-401.

Anzieu, D., Mathieu, M., Besdin, M., Guillaumin, J. \& Jacques, E. (1974). Psychanalyse du génie créateur. París: Dunod.

Aron, R. J. (1984). The art of art therapy. Nueva York: Brunner/Mazel. Aron, R. J. et al. (2001). Approaches to art therapy. (2a. ed.). Nueva York: Brunner-Routledge.

Benson, H. (1995). The relaxation response. Nueva York: Avon.

Beres, D. (1960). Perception, imagination, and reality. International Journal of Psychoanalysis, 41, 327-334.

Beres, D. (1965). Symbol and object. Bulletin of the Meaning Clinic, 3, 23-29.

Beres, D. (1968). The humanness of human beings. Psychoanalytic considerations. Psychoanalytic Quarterly, 37, 487-522.

Berger, A. (1968). L'art et la psychanalyse. París: Mouton.

Bowlby, J. (1969). Attachment and loss. Nueva York : Basic Books.

Brousselle, A. (1993). Dissonances. Bulletin de Psychologie, 411(46), 418.

Caïn, J. (1982). Psychanalyse et musique. París: Belles Lettres. 
Caïn, J. (1982). Tempo de psychoanalysis. Toulouse, Francia: Privat.

Chasseguet, S. J. (1971). Pour une psychanalyse de l'art et de la créativité. París: Payot.

Ferreira, O. J. (1990). Los colores de la música. Bogotá: Planeta.

Florance, J. (1992). Les effets de la théâtralité. Esquisses Psychanalytiques, 2, 10.

Freud, S. (1981). Pegan a un niño. En Obras Completas (Tomo 3, pp. 2465-2480). Madrid: Biblioteca Nueva.

Freud, S. (1981). La interpretación de los sueños en psicoanálisis. En Obras Completas (Tomo 1, pp. 343-7139). Madrid: Biblioteca Nueva.

Freud, S. (1981). El interés del psicoanálisis para la estética. En Obras Completas (Tomo 2, pp. 1864-1865). Madrid: Biblioteca Nueva.

Freud, S. (1981). El simbolismo en el sueño. En Obras Completas (Tomo 2, pp. 2212-2225). Madrid: Biblioteca Nueva.

Freud, S. (1981). Análisis de la fobia de un niño de cinco años. En Obras Completas (Tomo 2, pp. 1365-1440). Madrid: Biblioteca Nueva.

Freud, S. (1981). Lo inconsciente. En Obras Completas (Tomo 2, pp. 2063-2064). Madrid: Biblioteca Nueva.

Freud, S. (1981). Historia de una neurosis infantil. En Obras Completas (Tomo 2, pp. 1941-2000). Madrid: Biblioteca Nueva.

Freud, S. (1981). Un recuerdo infantil de Leonardo Da Vinci. En Obras Completas (Tomo 2, pp. 1577-1619). Madrid : Biblioteca Nueva. Fromm Reichmann, F. (1978). Psicoterapia intensiva en la esquizofrenia y en los maniaco depresivos (3a. ed.). Buenos Aires: Horme.

Heline, C. (1983). Healing and regeneration by the music and the color. Nueva York: Vorss and Co.

Jakob, I. Psychopathologie of expression and psychoanalysis. Pittsburgh, PA: University of Pittsburgh.

Joulia, M. C. (1993). Discours thérapeutique et discours artistique. Bulletin de Psychologie Française, 46(41), 611-612.

Klein, M. (1968). Amor, odio y reparación. Buenos Aires: Paidós. 
Klein, M. (1974). Algunas conclusiones sobre la vida del lactante. En Desarrollos del Psicoanálisis (Vol. 3). Buenos Aires: Paidós-Hormé. Klein, J. P. (1993). L'art comme processus de transformation. Bulletin de Psychologie Française, 46(41), 613-614.

Kofman, S. (1970). L'enfance de l'art. Une interprétation de l'esthétique Freudienne. París: Petite Bibliothèque Payot.

Kohut, H. (1951). The psychological significance of music activity. Music Therapy, 1, 151-158.

Lachman-Chapin, M. (2001). Self Psychology and art therapy technique. En J. Rubin (Ed.), Approaches to art therapy, theory and technique (pp. 66-78). Nueva York: Brunner-Routledge.

Landgarten, H. B. \& Lubbers, D. (1991). Adult art psychotherapy. Issues and applications. Nueva York: Brunner/Mazel.

Langer, M. (1979). Aporte kleiniano a la evolución instintiva. Buenos Aires: Paidós.

Laplanche, J. \& Pontalis, J. (1973). Vocabulaire de la Psychanalyse. París: Presses Universitaires de France.

Malchiodi, C. (1998). The art therapy sourcebook. Lincolnwood, IL: Lowell House.

Malchiodi, C. A. (2003). The art therapy and the brain. En C. Malchiodi (Ed.), Handbook of Art therapy. Nueva York: Guilford.

Marty, G. (1999). Psicología del arte. Madrid: Pirámide.

Mijolla, A. (1982). En guise d'ouverture. París: Belles Lettres.

Powell, A. (1990). Words and music: An unsung therapeutic alliance. Group Analysis, 23, 225-235.

Robinson, A. (2001). Object relations and art therapy. En R. J. Aron et al. (Eds.), Approaches to art therapy (pp. 54-65). Nueva York: Brunner-Routledge.

Rosalato, J. (1982). Pyschanalyse et musique. París: Belles Lettres.

Seashore, C. (1938). Psychology of music. Nueva York: Mc Graw Hill.

Smith, E. (1985). The body in psychotherapy. Jefferson, NY: McFarland.

Spaniol, S. (2003). Art therapy with adults with severe mental illness. En Handbook of Art Therapy (pp. 268-281). Nueva York: Guilford Press. 
Sullivan, H. S. (1978). Concepciones de la psiquiatría moderna. Buenos Aires: Psique.

Vick, R. M. (2003). A brief history of art therapy. En C. Malchiodi (Ed.), Handbook of Art Therapy (pp. 5-16). Nueva York: Guilford Press.

Virshup, E. (1985). Substance abuse and treatment (Vol. 2). Los Angeles, CA: Institute for Studies of Destructive Behavior.

Walter, D. (1990). Arts as communication. Group Analysis, 337-338.

Wilson, L. (2001). Symbolism and art therapy. En R. J. Aron et al. (Eds.), Approaches to art therapy (pp. 40-53). Nueva York: Brunner-Routledge.

Winnicott, D. (1971). Juego y realidad. Buenos Aires: Paidós.

Winnicott, D. (1971). Ego distortions in terms of true and false self: The maturational processes and the facilitating environment. Londres: Hogarth Press.

Recibido: 7 de agosto, 2011 Aceptado: 24 de mayo, 2012 